\title{
Business Cycles and Macroeconomic Policy in Emerging Market Economies
}

\author{
Philip R. Lane* \\ IIIS and Economics Department, Trinity College Dublin and CEPR \\ Revised: January 2003
}

\begin{abstract}
This paper argues that significant structural differences exist between industrial and emerging market economies. Cyclical fluctuations have been more extreme for the latter group and exacerbated by inappropriately procyclical macroeconomic policies. However, we argue that effective stabilization policies remain feasible for the emerging market economies, so long as these invest in developing a robust domestic institutional infrastructure.
\end{abstract}

\footnotetext{
*Prepared for the Council on Foreign Relations / International Finance conference on "Stabilizing the Economy: What Roles for Fiscal and Monetary Policy?", July $112002 . \quad$ I thank Rich Clarida, Benn Steil and an anonymous referee for comments. Email: plane@tcd.ie. Homepage: http://www.economics.tcd.ie/plane. Tel.: 353-1-6082259. Fax: 353-1-6772503. This work is part of a research network on 'The Analysis of International Capital Markets: Understanding Europe's Role in the Global Economy', funded by the European Commission under the Research Training Network Programme (Contract No. HPRN-CT-1999-00067).
} 


\section{Introduction}

Understanding business cycles and their implications for optimal monetary and fiscal policies remains a primary challenge for research economists. The slowdown in the industrial countries in 2001-2002 has prompted a renewed discussion about the appropriate policy response to signs of impending recession. For the emerging market economies, a similar debate also rolls on but is augmented by several additional factors that are not central to the contemporary experience of the industrial countries. Among these are: the risks of full-blown crises; contagion; time-varying external credit constraints; the currency denomination of liabilities; and domestic financial underdevelopment. Do these special features render counter-cyclical macroeconomic policy redundant or even counter-productive? Since economic fluctuations are typically larger and more persistent for these countries relative to the industrial nations, a lack of effective stabilization tools is especially costly. In this paper, we critically review the current state of play regarding the interaction of business cycles and macroeconomic policy in emerging market economies. In addition, we outline some proposals for reform that may lead to improved stabilization performance in the future.

The structure of the rest of the paper is as follows. In section 2, we provide an empirical characterization of some key stylized facts concerning the structure of industrial and emerging market economies and their cyclical performance. Section 3 analyses the challenges faced by emerging market economies in implementing optimal monetary, exchange rate and fiscal stabilization policies. We turn to proposals for reform in section 4 . Section 5 offers some concluding comments.

\section{Empirical Evidence on Business Cycles and Macro- economic Policy}

To provide a factual context for the discussion, we present in this section some empirical evidence on cyclical macroeconomic behavior for a panel of industrial, East Asian and Latin American and Caribbean countries. The 46 countries are listed in Table 1 and consist of 
22 industrial countries, 5 East Asian countries and 19 Latin American and Caribbean countries. ${ }^{1}$

We begin in Table 2 by examining some potential determinants of cross-sectional variation in output volatility across countries. ${ }^{2}$ It is well known that output volatility is inversely correlated with the level of development and we include output per capita as a regressor in each specification in columns (1)-(5) of Table $2 \cdot{ }^{3}$ It is also plausible that smaller countries may face higher volatility, since the scope for sectoral and regional diversification is more limited. In similar fashion, countries that have high trade volumes may be more vulnerable to external shocks, as may countries with volatile terms of trade. We also consider the role of domestic financial development - a shallow financial system may exacerbate output fluctuations through a variety of mechanisms. Finally, countries with large net external liabilities may also be more volatile, if balance sheet channels act to magnify the impact of cyclical shocks.

The results in Table 2 confirm a strong inverse relation between output per capita and volatility, even controlling for other factors. Indeed, the simple regression in column (2) explains 50 percent of the variation in output volatility. There is also support for the notion that smaller countries are more volatile. However, the evidence here is that trade openness reduces volatility, in contrast to what might be expected. Finally, there is weaker evidence that terms of trade volatility contributes to output volatility but there is no cross-sectional relation between volatility and domestic financial depth or the net foreign asset position. ${ }^{4}$

These findings help to explain why output volatility is so much different in emerging markets as compared to the industrial nations. Table 3 shows the group variation in the

\footnotetext{
${ }^{1}$ Several interesting countries (eg Hong Kong and Singapore) are excluded from the sample due to the lack of some key data. Most of sub-Saharan Africa is largely isolated from international capital markets and so these countries face a different macroeconomic environment (Honohan and Lane 2001).

${ }^{2}$ We also ran the same regressions for consumption volatility: the results were very similar.

${ }^{3}$ See also Kraay and Ventura (2000) on this correlation.

${ }^{4}$ That financial depth and the net foreign asset position are unimportant in this basic cross-sectional specification does not rule out more subtle non-linear effects or an important role in explaining time-series dynamics. Exploring these other mechanisms is deferred to future research.
} 
explanatory variables employed in Table $2 .^{5}$ East Asia and the Latin American/Caribbean nations are far poorer than the industrial countries, have much more volatile terms of trade and are less financially developed. Latin America in particular is also characterized by low trade volumes and relatively small country size. Another clear difference is that the emerging market economies carry significant net foreign liability positions, whereas the typical industrial country is close to external balance. ${ }^{6}$

In addition, these groups vary not only in the amplitude of fluctuations but also in the cyclical comovement of key macroeconomic variables with output. As a simple and concise way to capture cyclical patterns, Table 4 reports results for the key coefficients from panel regressions of the form

$$
D\left(X_{i t}\right)=\alpha_{i}+\phi_{t}+\beta_{1} * I N D * C Y C_{i t}+\beta_{2} * E A S I A * C Y C_{i t}+\beta_{3} * L A C * C Y C_{i t}+\varepsilon_{i t}
$$

where $X_{i t}$ denotes the macroeconomic variable of interest, $C Y C_{i t}$ is the growth rate of output and IND, EASIA and $L A C$ are 0-1 group dummies. ${ }^{7}$ In row (1), we see that the savings rate is appropriately procyclical in all groups but that it is far more responsive (by a factor of 2.8) for the industrial countries than for the LAC group, with the EASIA group in the middle. ${ }^{8}$ Put differently, output volatility differentials between the industrial and emerging market nations are further magnified with respect to the variation in consumption volatility across the groups.

We consider the cyclical behavior of the current account surplus in row (2) of Table 4. The current account surplus is countercyclical for all groups, with the cyclical sensitivity being substantially larger for the EASIA group. Although a procyclical current account may be helpful in accumulating a buffer stock of net foreign assets during good times, the

\footnotetext{
${ }^{5}$ All the data are averaged over 1975-2000.

${ }^{6}$ Emerging markets also typically have riskier balance sheets in that external liabilities are more heavily tilted towards debt rather than equity instruments (Lane and Milesi-Ferretti 2001).

${ }^{7}$ It makes little difference if we employ other measures of the cyclical component of output, such as the Hodrick-Prescott or band-pass filters. Allowing for asymmetrical responses to expansions versus contractions also does not substantially alter the findings.

${ }^{8}$ If we allow for an asymmetry between output expansions and contractions, a notable feature is the LAC group fail to increase the savings rate during recessions. See also Lane and Tornell (1998).
} 
countercyclical pattern is well explained by the procyclical nature of investment spending. Taken in conjunction with the savings equation in row (1), the similar coefficients for the IND and LAC groups hide a different pattern: investment spending is much more procyclical in the industrial countries than in the Latin American/Caribbean region but compensated by a more procyclical pattern in savings.

We turn to fiscal policy indicators in rows (3)-(4) of Table 4. Row (3) shows that the fiscal surplus is significantly procyclical in the IND and EASIA groups (and is more procyclical in the former group) but that the LAC group fails to engage in budgetary smoothing. Since row (4) shows that the difference does not come from the cyclical behavior of the tax ratio, it seems that the IND group are better able to limit procyclicality in government spending. Finally, the cyclical behavior of the real exchange rate is documented in row (5) of Table 4. Its behavior is essentially acyclical for the panel of industrial countries but is strongly procyclical for the emerging market groups: real appreciations occur during booms and depreciations during contractions. ${ }^{9}$ This pattern means that the external value of domestic output is even more procyclical than when deflated by the domestic price level.

In summary, this brief empirical review shows that the emerging market economies have been structurally more exposed to business cycles than are the industrial nations. In addition, it seems that they also have coped less well in smoothing the impact of fluctuations. In the next section, we critically analyze role of macroeconomic policy over the business cycles for these countries.

\section{Macroeconomic Policy in Industrial and Emerging Market Economies}

In this section, we review the domestic and external factors that contribute to procyclical pressures on macroeconomic policies in emerging market economies. We first discuss mon-

\footnotetext{
${ }^{9}$ We do not address the causal mechanisms behind the correlation of output growth and the real exchange rate.
} 
etary and exchange rate strategies in responding to cyclical fluctuations, before turning to the role of fiscal instruments in stabilization policy.

\subsection{Monetary and Exchange Rate Policies as Stabilization De- vices}

The traditional Mundell-Fleming model has it that flexible exchange rates are desirable if prices or wages are sticky and the economy is primarily disturbed by real shocks. In contrast, a fixed exchange rate system is superior if nominal shocks predominate. Benchmark models in the more recent "new open economy macroeconomics" style also largely accord with these broad findings. As a prelude, it is also worth emphasizing that the objective of optimal macroeconomic policy is not to suppress all output fluctuations. ${ }^{10}$ For instance, the economy should adjust to even temporary productivity or terms of trade shocks however, in the presence of nominal rigidities, efficient adjustment requires policy activism rather than an acyclical stance. Product or factor market distortions may also justify countercyclical interventions: for instance, an optimizing central bank will want to offset "cost-push" shocks such as attempts by unions to raise wage premia.

However, several features are missing from these standard models that may be required to understand business cycles in emerging market economies. In particular, there is a substantial recent body of work that points to the importance of financial factors in understanding exchange rates in emerging market economies. Two main factors are highlighted in this literature: (a) the presence of substantial foreign-currency debt means that exchange rate movements lead to variation in the net worth of investors; and (b) credit market frictions mean that investment may be constrained by the quality of the balance sheet. ${ }^{11}$ For

\footnotetext{
${ }^{10}$ Lucas (2003) provides an overview of the literature that emphasizes that optimal stabilization policy in industrial countries would deliver only small welfare gains.

${ }^{11}$ Of course, incorporating balance sheet effects is also helpful in understanding business cycles in the advanced economies (Bernanke et al 1999). However, a lower level of financial development means that such considerations are more important for the emerging market economies. Moreover, liabilities are largely denominated in domestic currency for the industrial countries.
} 
extreme cases (e.g. a very high debt-export ratio, a very weak real exchange rate and a high sensitivity of investment to net worth), it is possible to construct multiple equilibria scenarios in which self-fulfilling shifts in expectations can move an economy from prosperity to a crisis (Aghion et al 2001, Velasco 2001). Moreover, in such extreme circumstances, exchange rate devaluations are not helpful since the negative impact of the increase in the burden of foreign-currency debt dominates all other effects.

Although such crisis situations are all too familiar, the mere facts that external-currency debt exists and there are binding financial constraints do not mean that exchange rate flexibility is generally undesirable. Rather, a number of authors have shown that, except in the extreme situations outlined above, these features actually reinforce the need for a countercyclical monetary policy in responding to shocks (Cespedes et al 2001, Gertler et al 2001, Devereux and Lane 2001, Velasco 2001). Although depreciation does raise the real burden of foreign-currency debt, this is typically outweighed by the fact that (in addition to its regular Keynesian effects) stimulating domestic output raises profits, which improves the net worth of investors and relaxes credit constraints. Furthermore, expansionary monetary policy improves domestic liquidity, which can partially compensate for a shallow domestic financial sector and a deterioration in access to external capital markets (Caballero 2002). In numerical simulations in which credit constraints and foreign-currency debt levels are set at empirically reasonable levels, Devereux and Lane (2001) find that the presence of financial constraints typically does increase the magnitude of business cycle fluctuations but does not alter the relative ranking of alternative monetary and exchange rate regimes. ${ }^{12}$

However, there are other circumstances that also may favor an exchange rate peg or at least limiting the scale of exchange rate movements. Devereux and Lane (2002) and Christiano et al (2002) emphasize that exchange rate movements can be especially costly if imported intermediates are important in domestic production and is financed by foreigncurrency working capital. Under these circumstances, depreciation depresses output by

\footnotetext{
${ }^{12}$ Broda (2001) provides econometric panel-VAR evidence for developing countries that adjustment to terms of trade shocks is facilitated by a floating exchange rate. Hoffmann (2002) conducts a similar analysis for shocks to world interest rates and world output.
} 
directly increasing production costs, rather than just operating on investment demand. Cavallo et al (2002) highlight another cost to floating: if there is a downward-sloping demand schedule for domestic shares, devaluation and a binding financial constraint may compel indebted domestic agents to recapitalize by selling equity at fire-sale prices, with a depressing effect on long-run consumption levels.

Both types of friction serve to highlight that exchange rate flexibility is of limited value for financially fragile economies. In their empirical work, Devereux and Lane (2002) find that a greater dependence on foreign-currency debt loaned by a given creditor country makes it more likely that a developing country will minimize bilateral exchange rate volatility vis-a-vis that currency. It is noteworthy that this effect becomes less important, the greater is the depth of the domestic financial system, which suggests that the vulnerability associated with foreign-currency debt is eroded by institutional development.

As is emphasized by Caballero (2002), Calvo and Reinhart (2002) and Mendoza (2002), exchange rate depreciation further loses its potency if the monetary authority lacks credibility. Under such circumstances, even a temporary monetary relaxation may be perceived as heralding a persistent switch to a loose money regime, with a negative impact on confidence and an increase in the risk premium demanded by foreign investors. This is really a two-step hypothesis. First, can emerging market economies feasibly develop credible domestic monetary institutions? Second, are the international capital markets sufficiently discriminating to reward those countries that succeed in this endeavour? If either question is answered in the negative, it may be economic for these countries to take the alternative course of importing credibility by surrendering monetary independence via dollarization or euroization. Related to the latter, the widespread withdrawal from emerging markets in the wake of the 1998 Russian default has been taken by some experts to signify that even well-behaved individual countries are vulnerable to a shift in investor sentiment towards an entire asset class.

Drawing on his joint work with Guillermo Calvo, Mendoza (2002) lays out several reasons why such rational contagion may be possible. Among these are (a) the entry of many 
emerging nations into the international capital markets means that a diversified investor has little reason to pay fixed costs to acquire information about individual countries; (b) the reward system for institutional investors means that herding is a reasonable strategy, since it is imperative to avoid under-performance relative to the market benchmark; and (c) the tracking of large informed investors that specialize in emerging markets mean that idiosyncratic shocks to these traders (eg margin calls on specific positions) can be interpreted by the broader market as a negative signal regarding the entire asset class. However, the discriminating response of the capital markets to the Argentina crisis suggest that contagion is not inevitable and that country-specific characteristics do indeed matter for market access. $^{13}$

\subsection{Fiscal Policy over the Cycle}

We have focused our attention on the appropriate monetary and exchange rate strategies for emerging market economies. Is there a role for a countercyclical fiscal policy? In terms of timeliness and flexibility, we know that fiscal policy is at a severe disadvantage as compared to monetary interventions. We also understand much less about the effectiveness and transmission mechanism for fiscal policy (Perotti 2002). At one level, some fiscal stabilization is achieved via the operation of automatic stabilizers. However, this is less likely to be effective for developing countries that lack the extensive social insurance and income tax systems that characterize the industrial nations. ${ }^{14}$ In related fashion, to the extent that the government sector is also smaller as a proportion of total output, it is also the case that aggregate output in emerging economies is more exposed to market fluctuations. ${ }^{15}$

Moreover, the history of fiscal policy in both industrial and developing countries is that

\footnotetext{
${ }^{13}$ See Hausmann and Velasco (2002) for a review of the Argentinian crisis.

${ }^{14}$ Of course, the upside of limited automatic stabilizers is that the output response to positive productivity innovations is less inhibited.

${ }^{15}$ Gali (1994) and Fatas and Mihov (2001) document an inverse relation between government size and output volatility. Of course, its impact on stabilization policy is not the primary criterion by which to judge the appropriate size of government for a given country.
} 
it has often been procyclical in nature (Gavin and Perotti 1997, Talvi and Vegh 2000, Lane 1998, Lane 2002b), with disproportionate spending increases combined with tax reductions during expansions leaving little slack to cope with downturns. Procyclical tendencies are likely to be most pronounced in countries characterized by political systems with multiple fiscal veto points and where output volatility is higher (Lane 2002b, Stein et al 1999, Talvi and Vegh 2000). The former can be rationalized by the voracity effect modelled by Lane and Tornell (1998) and Tornell and Lane (1999): if there are multiple actors with access to the fiscal process, the intensity of appropriative activity rises with the output growth rate. ${ }^{16}$ The latter is highlighted by Talvi and Vegh (2000) and is based on the proposition that the greater is the amplitude of the cycle, the larger is the budget surplus that should be run during output expansions. Since the political feasibility of running a surplus is sharply declining in its magnitude, a country experiencing a large boom may opt to cut taxes and/or raise spending, even if the tax-smoothing principle indicates that a large surplus should be accumulated.

A basic problem in determining the appropriate fiscal stance is assessing the trend for potential output. Clearly, this is a problem for even the most advanced economies but it is exacerbated for developing countries for several reasons. First, potential output for these economies is largely determined by their ability to adopt new technologies invented elsewhere and accumulate capital. Both drivers are highly variable in an open economy, since we know that growth miracles can occur if the institutional and policy structures are correct but that stagnation and sustained capital flight are also feasible outcomes. In such an environment in which countries are attempting to undertake various structural reform and modernization programs, it is very difficult to assess whether a given output movement

\footnotetext{
${ }^{16}$ In general, the common pool problem leads to fiscal indiscipline. The voracity effect model shows how the fiscal externality problem dynamically varies with the growth rate of the economy. Of course, the common pool problem may also aggravate the difficulty of fiscal adjustment to downturns, for the "war of attrition" reasons highlighted by Alesina and Drazan (1991). It is also worth remarking that multiple fiscal veto points may make the political system more stable (Henisz 2000). It follows that a trade-off may exist between fiscal predictability and the capacity to engage in discretionary countercyclical fiscal policy.
} 
is permanent in nature or will be reversed at a later date. Excessive optimism concerning prospects for output growth may lead to a fiscal relaxation that will have to be reversed at a later date. Moreover, it is precisely negative information about the economy that will induce the fiscal adjustment, such that the correction may take place just as the economy is already slowing down.

These dynamics represent another manifestation of fiscal procyclicality, with a recession precipitating a budgetary correction. If an unsustainable fiscal position is the source of the downturn or is an important aggravating factor, a fiscal contraction is surely part of the appropriate remedy in order to avoid a spiralling debt-export ratio and rising interest rate premium. However, it is increasingly accepted that there is a low likelihood of an "expansionary fiscal contraction" scenario, whereby the fiscal reform in itself generates a sharp recovery in output (Giavazzi and Pagano 1990). Rather, it is desirable from a stabilization perspective that an easing of the monetary stance accompany a fiscal contraction.

Even in regard to the original case studies cited by this literature, there has been considerable revisionism. For instance, in the case of Ireland, the consensus view now is that the fact that output grew quickly in the wake of the 1987 fiscal reform can be better explained by a mix of a fortuitous contemporaneous boom in its major export markets plus a substantial exchange rate devaluation in the summer of 1986 (Honohan and Walsh 2002).

Rather, it is desirable from a stabilization perspective that an easing of the monetary stance accompany a fiscal contraction. It is also preferable that a fiscal correction be opportunistically timed to coincide with an upswing in the economy but this tactic is only feasible if the long-term fiscal position is sustainable, thereby allowing the government some flexibility in formulating a fiscal correction strategy. Finally, the findings of Alesina and Perotti (1995) for the OECD reinforce the important point that the confidence-building element of a fiscal reform relies on it being based on sustainable reductions in government spending rather than increases in taxation. However, it is not clear that the same result would apply for those developing countries for which the basic fiscal problem is an inadequate tax base.

A final source of fiscal procyclicality lies in the intrinsic dynamics of government debt. 
Clearly, the primary surplus required to stabilize the debt-output ratio is increasing in the interest rate paid on the debt and decreasing in the growth rate. Since the country risk premium component of the interest rate is itself also inversely related to the growth rate, a given budget balance is associated with a faster rise in the debt-output ratio during slowdowns as compared to expansions. If the debt is denominated in foreign-currency, an additional factor is that a real depreciation raises the burden of debt in terms of domestic output, which Table 4 indicates is also most likely to occur during downturns.

From this discussion, it is evident that governments in emerging market economies face a major challenge in ensuring that fiscal policy is not exacerbating cyclical fluctuations, let alone acting as a stabilization instrument. In the next section, we turn to proposals for reform that may improve their capacity to run counter-cyclical macroeconomic policies in emerging market economies.

\section{Proposals for Reform}

Can stabilization policies in emerging market economies be improved? In this section, we discuss some reforms that can combat the forces that generate procyclical pressures on policy formation. A general theme behind these reform proposals is that embedding policy decisions in a formal institutional framework can do much to reduce uncertainty about medium-term economic prospects, thereby reducing the risk of policy-induced volatility.

First, monetary stability remains a paramount target. Except in rare cases, dollarization or euroization is unlikely to be an optimal strategy in pursuit of this goal. In general, this option should only be entertained for very small countries or if the domestic institutional infrastructure is deemed beyond repair. Dornbusch and Giavazzi (1998) advocate euroization for the European accession countries. However, that is a substantially different debate, since the terminal goal for these countries is membership of the eurozone. As such, unilateral euroization is just a transitional stage towards full membership of the European monetary union. For Latin America, the option of membership of a commonly-managed currency zone including the United States is quite remote. 
It should be recognized that such a policy works best if domestic price and wage setters adapt flexibly to the elimination of the devaluation option: however, the same weaknesses that prevent domestic institution building may also make less likely such responsiveness in labor and product markets. Moreover, if the option to devalue the nominal exchange rate is eliminated, shocks that require significant real depreciation can only be accommodated via price deflation (Cespedes et al 2001). However, a sustained period of deflation is costly in that it impairs the ability of indebted firms and governments to recover from negative disturbances. Reinhart and Rogoff (2002) document that deflations are indeed a regular occurrence among members of a currency union: for instance, they note that members of the CFA zone experienced deflation about 28 percent of the time during 1970-2001.

Rather, for the vast majority of emerging market economies, the preferred route to monetary stability is to retain some degree of monetary independence and develop a robust and transparent framework to guide interest rate decisions. In line with recent developments in the industrial nations, the most obvious candidate is to adopt an inflation targeting approach in setting monetary policy. ${ }^{17}$ An inflation target can provide the medium-term anchor that assures investors that price shocks will be met by an aggressive policy response. Of course, credible pursuit of an inflation target requires a capable and autonomous central bank that is demonstrably committed to medium-term price stability. Although the process of establishing a credible inflation target may involve a prolonged period of temporarily high real interest rates, the payoff will be a improved monetary climate. Central to improved stabilization performance is that an inflation target that anchors medium-term expectations would permit the central bank to smooth cyclical shocks without inducing countervailing shifts in long-term interest rates.

Although the advantages of inflation targeting are by now well understood, there are still a number of outstanding issues in terms of the execution of monetary policy. For open economies, the selection of the appropriate target price index is a substantive issue. In general, an optimizing central bank should target a price index that reflects those sectors

\footnotetext{
${ }^{17}$ See Mishkin and Savastano (2002) for an analysis of the recent implementation of inflation targeting in a number of developing countries.
} 
in the economy that exhibit nominal rigidities (Clarida et al 2001). One implication is that if the rate of pass through is rapid from the exchange rate to the retail prices of imported goods, it may make sense to target just a bundle of domestically-produced goods. However, if pass through is low, the overall CPI index may be a more reasonable target (Devereux and Lane 2001). As average inflation rates fall for the emerging market economies, the empirical evdience is that the degree of pass through also declines: this further improves the effectiveness of monetary policy in adjusting to shocks. ${ }^{18}$

In a similar spirit, a formal medium-term framework for the conduct of fiscal policy is also highly desirable in order to insulate it from the pressures that generate procyclicality. A number of commentators have recommended the establishment of an independent Fiscal Policy Council (FPC) that would each year set a deficit limit in order to ensure a sustainable medium-term debt level. ${ }^{19}$ Politicians would have to work within that deficit limit in taking decisions on public expenditure and taxation. A FPC may be especially useful in political systems that are characterized by high fragmentation, polarization and frequent electoral turnover, since these factors are important contributors to procyclical fiscal behavior. Enshrining the role of a FPC in legislation would be more effective than informal procedures that are more easily subject to revision. In general, a FPC has a similar motivation to the EU Stability and Growth Pact but is a more flexible concept that would allow room for warranted counter-cyclical fiscal management.

A FPC system promises to offer much improved fiscal stability. However, there are many other aspects of fiscal policy in need of reform. Structural innovations to expand

\footnotetext{
${ }^{18}$ We also note that policymakers in emerging market economies are even more afflicted by the presence of uncertainty than their counterparts in the industrial nations (Lane 2002a). Although the classic result is that parameter uncertainty should induce caution in policymaking, a large recent literature finds that other forms of uncertainty should call forth a more aggressive stabilization policy (see Lane 2002a for a review).

${ }^{19}$ See the proposals by Eichengreen et al (1999) and Wyplosz (2002) and the commentaries by Perry (2002) and De Gregorio (2002). Annett (2002) and von Hagen (2002) provide general surveys of the literature on fiscal procedures. Fatas and Mihov (2002) provide some recent empirical evidence on the effectiveness of institutional restrictions on fiscal policy.
} 
the tax base and improve compliance would be helpful on the revenue side. For federal systems, it is also clear that common pool problems between the central and provincial governments must be resolved by addressing free-rider incentive problems.

Although reform of domestic monetary and fiscal institutions promises the largest payoff in terms of improved stabilization policies, policy initiatives to address imported instability from the international capital markets may also be useful. Of course, domestic reform in itself will be rewarded by a more benign attitude on the part of international investors. However, there still remains exposure to externally-generated capital market shocks. As is elaborated by Caballero (2002b, 2003), part of the solution can be found in exploiting the financial engineering opportunities that are available in contemporary financial markets. Since the cyclical shocks facing emerging market economies are correlated with external financial indicators (e.g. commodity prices, the high-yield spread in corporate debt markets), it should be possible to design contingent-claim securities that better insulate these countries from external disturbances. Since it is well understood that externality effects may inhibit the establishment of new financial markets, this may require intervention by the international financial institutions to support the trading of such contingent-payoff securities. $^{20}$

As such, the current Sovereign Debt Restructuring Mechanism (SDRM) initiative that is intended to improve the resolution of crises may be but the first step in a deeper process of reconfiguring the international capital market environment that is faced by emerging market economies. Indeed, improving ex-ante risk sharing opportunities would generate more widespread gains than simply focusing on initiatives to reduce the costs of ex-post crises. Of course, there is also scope for financial contracts that specify a payoff that is conditional on domestic macroeconomic performance: however, moral hazard means that the introduction of such securities would be much more challenging. ${ }^{21}$

Clearly, these individual reforms have interaction effects but the good news is that these are largely mutually reinforcing. Medium-term monetary and fiscal stability are

\footnotetext{
${ }^{20}$ See Allen and Gale (1994) on the frictions that lead to missing financial markets.

${ }^{21}$ See also Shiller (1993) and Borensztein and Mauro (2002).
} 
complementary forces; domestic stability is enhanced by greater insulation from external shocks; and the default risk on even contingent-claim securities is enhanced by internal reforms that ensure debt sustainability. Finally, these reforms must be supported by a sound and well-regulated banking system. In this regard, it is important that the banking sectors in these countries are held to higher standards that are less exposed to procyclical forces than are the mininum requirements laid out in the Basel II accord. Of course, in the opposite direction, improved macroeconomic stability also greatly reduces the risk of financial and banking crises.

\section{Conclusions}

The empirical evidence in this paper confirms that emerging market economies have experienced much more volatile output and income fluctuations and that these have been further exacerbated by procyclical policies. We have described the domestic and external constraints that contribute to these patterns. However, we have also outlined institutional reforms in the conduct of monetary and fiscal policies that can do much to improve the capacity to stabilize cyclical fluctuations. Although the case for inflation targeting is by now widely accepted and it is being adopted by an increasing number of countries, relatively less progress has been made in designing and implementing new fiscal procedures. New forms of international financial engineering that may also help to stabilize emerging markets are at an even earlier stage of development. Further research on all these fronts is warranted.

Establishing a stable macroeconomic environment is but a first step in developing a highquality overall domestic institutional infrastructure. ${ }^{22}$ However, institutional innovation in the macroeconomic policy sphere may provide the foundations for the difficult process of implementing the long-term structural reforms that are required for the full development of the economic and social potential of these countries.

\footnotetext{
${ }^{22}$ See Navia and Velasco (2002) on the political economy of 'second-generation' reforms.
} 


\section{References}

Aghion, Philippe, Philippe Bacchetta, and Abhijit Banerjee (2001), "Currency Crises and Monetary Policy in an Economy with Credit Constraints," European Economic Review 47, 1121-1150.

Alesina, Alberto and Allan Drazen (1991), "Why Are Stabilizations Delayed?," American Economic Review 81, 1170-1188.

Alesina, Alberto and Roberto Perotti (1995), "Fiscal Expansions and Adjustments in OECD Countries," Economic Policy 21, 205-240.

Allen, Franklin and Douglas Gale (1994), Financial Innovation and Risk Sharing, Cambridge, MA: The MIT Press.

Annett, Anthony (2002), "Politics, Government Size and Fiscal Adjustment in the OECD," International Monetary Fund Working Paper No. WP/02/162.

Bernanke, Ben, Mark Gertler and Simon Gilchrist (1999), "The Financial Accelerator in a Quantitative Business Cycle Model," in John Taylor and Michael Woodford, eds, Handbook of Macroeconomics, Volume 1c, Amsterdam: North Holland, 1341-1393.

Borensztein, Eduardo R. and Paolo Mauro (2002), "Reviving the Case for GDP-Indexed Bonds," International Monetary Fund Policy Discussion Paper No. 02/10.

Broda, Christian (2001), "Terms of Trade and Exchange Rate Regimes in Developing Countries," mimeo, Federal Reserve Bank of New York.

Caballero, Ricardo (2002a), "Emerging Markets' Economics," mimeo, MIT.

Caballero, Ricardo (2002b), "Coping with Chile's External Vulnerability: A Financial Problem," mimeo, MIT.

Caballero, Ricardo (2003), "The Future of the IMF," mimeo, MIT. 
Cavallo, Michele, Kate Kisselev, Fabrizio Perri and Nouriel Roubini (2002), "Exchange Rates Overshooting and the Costs of Floating," mimeo, New York University.

Calvo, Guillermo A. and Carmen M. Reinhart (2002), "Fear of Floating," Quarterly Journal of Economics 107, 379-408.

Cespedes, Luis Felipe, Roberto Chang, and Andres Velasco (2000), "Balance Sheets and Exchange Rate Policy," NBER Working Paper No. 7840.

Christiano, Lawrence J., Christopher Gust and Jorge Roldos (2002), "Monetary Policy in a Financial Crisis," NBER Working Paper No. 9005.

Clarida, Richard, Jordi Gali and Mark Gertler (2001), "Optimal Monetary Policy in Open versus Closed Economies: An Integrated Approach," American Economic Review 91, 248-252.

De Gregorio, Jose (2002), "Macroeconomic Management in Emerging Economies and the International Financial Architecture," mimeo, Central Bank of Chile.

Devereux Michael B. and Philip R. Lane (2001), "Exchange Rates and Monetary Policy for Emerging Market Economies," CEPR Discussion Paper No. 2874.

Devereux Michael B. and Philip R. Lane (2003), "Understanding Bilateral Exchange Rate Volatility," Journal of International Economics, forthcoming.

Dornbusch, Rudiger and Francesco Giavazzi (1998), "Hard Currencies and Sound Credit: A Financial Agenda for Central Europe," mimeo, MIT.

Eichengreen, Barry, Ricardo Hausmann and Jurgen von Hagen (1999), "Reforming Budgetary Institutions in Latin America: The Case for a National Fiscal Council," Open Economies Review 10, 415-442.

Fatas, Antonio and Ilian Mihov (2001), "Government Size and Automatic Stabilizers: International and Intranational Evidence," Journal of International Economics 55, 3-28. 
Fatas, Antonio and Ilian Mihov (2002), "The Case for Restricting Fiscal Policy Discretion," mimeo, INSEAD.

Gali, Jordi (1994), "Government Size and Macroeconomic Stability," European Economic Review 38, 117-132.

Gertler, Mark, Simon Gilchrist and Fabio Natalucci (2001), "External Constraints on Monetary Policy and The Financial Accelerator," mimeo, New York University.

Giavazzi, Francesco and Marco Pagano (1990), "Can Severe Fiscal Contractions be Expansionary? Tales of Two Small European Countries," NBER Macroeconomics Annual 4, Cambridge, MA: The MIT Press, 75-111.

Hausmann, Ricardo, Ugo Panizza and Ernesto Stein (2001), "Why Do Countries Float the Way They Float?," Journal of Development Economics 66, 387-414.

Hausmann, Ricardo and Andres Velasco (2002), "The Argentine Collapse: Hard Money's Soft Underbelly," mimeo, Harvard University.

Henisz, Witold (2000), "The Institutional Environment for Economic Growth," Economics and Politics 12, 1-31.

Hoffmann, Mathias (2002), "Fixed versus Flexible Exchange Rates: A Panel VAR Approach," mimeo, Trinity College Dublin.

Honohan, Patrick and Philip R. Lane (2001), "Will the Euro Stimulate More Monetary Unions in Africa?," in: Charles Wyplosz, Ed., EMU and Its Impact on Europe and Developing Countries, Oxford University Press, New York, 315-338.

Honohan, Patrick and Brendan Walsh (2002), "Catching Up with the Leaders: The Irish Hare," Brookings Papers on Economic Activity, forthcoming.

Kraay, Aart and Jaume Ventura (2000), "Comparative Advantage and the Cross-Section of Business Cycles," mimeo, MIT. 
Lane, Philip R. (1998), "On the Cyclicality of Irish Fiscal Policy," Economic and Social Review 29, 1-16.

Lane, Philip R. (2002a), "Monetary-Fiscal Interactions in an Uncertain World: Lessons for European Policymakers," mimeo, Trinity College Dublin.

Lane, Philip R. (2002b), "The Cyclical Behaviour of Fiscal Policy: Evidence from the OECD," Journal of Public Economics, forthcoming.

Lane, Philip R. and Aaron Tornell (1998), "Why Aren't Latin American Savings Rates Procyclical?," Journal of Development Economics 57, 185-200

Lane, Philip R. and Gian Maria Milesi-Ferretti (2000), "The Transfer Problem Revisited: Real Exchange Rates and Net Foreign Assets," CEPR Discussion Paper No. 2511.

Lane, Philip R. and Gian Maria Milesi-Ferretti (2001), "The External Wealth of Nations: Measures of Foreign Assets and Liabilities for Industrial and Developing Nations," Journal of International Economics 55, 263-294.

Lane, Philip R. and Gian Maria Milesi-Ferretti (2002a), "External Wealth, the Trade Balance and the Real Exchange Rate," European Economic Review 46, 1049-1071.

Lane, Philip R. and Gian Maria Milesi-Ferretti (2002b), "Long-Term Capital Movements," NBER Macroeconomics Annual 16, Cambridge, MA: The MIT Press, .

Lane, Philip R. and Gian Maria Milesi-Ferretti (2003), "International Financial Integration," International Monetary Fund Staff Papers, forthcoming.

Lane, Philip R. and Roberto Perotti (2003), "The Importance of Composition of Fiscal Policy: Evidence from Different Exchange Rate Regimes," Journal of Public Economics, forthcoming.

Lucas, Robert E. Jr. (2003), "Macroeconomic Priorities," American Economic Review, forthcoming. 
Mendoza, Enrique (2002), "Why Should Emerging Economies Give Up National Currencies: A Case for 'Institutions Substitution'," NBER Working Paper No. 8950.

Mishkin, Frederic S. and Miguel A. Savastano (2002), "Monetary Policy Strategies for Emerging Market Countries: Lessons from Latin America," Journal of Comparative Economics, forthcoming.

Navia, Patricio and Andres Velasco (2002), "The Politics of Second Generation Reforms in Latin America," mimeo, Harvard University.

Perotti, Roberto (2002), "Estimating the Effects of Fiscal Policies in OECD Countries," Journal of the European Economic Association, forthcoming.

Perry, Guillermo (2002), "Can Fiscal Rules Reduce Macroeconomic Volatility in LAC?," mimeo, The World Bank.

Rogoff, Kenneth S. and Carmen Reinhart (2002), "The Modern History of Exchange Rate Arrangements: A Reinterpretation," NBER Working Paper No. 8963.

Shiller, Robert (1993), Macro Markets: Creating Institutions for Managing Society's Largest Economic Risks, Oxford, UK: Clarendon Press.

Stein, Ernesto, Ernesto Talvi and Alexandre Gristani (1999), "Institutional Arrangements and Fiscal Performance: The Latin American Experience," in James M. Poterba and Jurgen M. von Hagen (Eds) Fiscal Institutions and Fiscal Performance. University of Chicago Press, Chicago IL, 103-134.

Talvi, Ernesto and Carlos Vegh (2000), "Tax Base Variability and Procyclical Fiscal Policy," NBER Working Paper No. 7499.

Tornell, Aaron and Philip R. Lane (1999), "The Voracity Effect," American Economic Review 89, 22-46.

Velasco, Andres (2001), "The Impossible Duo? Globalization and Monetary Independence in Emerging Markets," mimeo, Harvard University. 
Von Hagen, Jurgen (2002), "Fiscal Rules, Fiscal Institutions and Fiscal Performance," Economic and Social Review 33, 263-284.

Wyplosz, Charles (2002), "'Fiscal Discipline in Emerging Market Economies: How to Go About It?," mimeo, Graduate Institute for International Studies. 
Table 1: Country List

\begin{tabular}{lll}
\hline United States & Norway & Mexico \\
Canada & Portugal & Nicaragua \\
Australia & Spain & Panama \\
New Zealand & Sweden & Paraguay \\
Japan & Switzerland & Peru \\
Austria & United Kingdom & Trinidad\&Tobago \\
Belgium & Argentina & Uruguay \\
Denmark & Bolivia & Venezuela \\
Finland & Brazil & Jamaica \\
France & Chile & Indonesia \\
Germany & Colombia & Korea \\
Greece & Costa Rica & Malaysia \\
Iceland & Ecuador & Philippines \\
Ireland & El Salvador & Thailand \\
Italy & Guatemala & \\
Netherlands & Honduras & \\
\hline
\end{tabular}


Table 2: Determinants of Output Volatility

\begin{tabular}{lllllll}
\hline & $(1)$ & $(2)$ & $(3)$ & $(4)$ & $(5)$ & $(6)$ \\
\hline constant & 10.5 & 13.0 & 17.2 & 16.1 & 15.7 & 14.7 \\
& $(7.76)^{* * *}$ & $(6.22)^{* * *}$ & $(4.76)^{* * *}$ & $(4.31)^{* * *}$ & $(4.02)^{* * *}$ & $(3.19)^{* * *}$ \\
GDP-PC & -0.83 & -0.82 & -0.82 & -0.65 & -0.63 & -0.63 \\
& $(5.86)^{* * *}$ & $(5.97)^{* * *}$ & $(5.85)^{* * *}$ & $(3.64)^{* * *}$ & $(2.5)^{* *}$ & $(2.02)^{*}$ \\
Size & & -0.15 & -0.27 & -0.26 & -0.25 & -0.20 \\
& & $(2.07)^{* *}$ & $(2.93)^{* * *}$ & $(2.91)^{* * *}$ & $(2.5)^{* *}$ & $(1.86)^{*}$ \\
Trade & & & -0.61 & -0.84 & -0.83 & -0.72 \\
& & & $(1.41)$ & $(1.98)^{*}$ & $(2.13)^{* *}$ & $(1.85)^{*}$ \\
Vol(TT) & & & & 0.19 & 0.19 & 0.12 \\
& & & & $(1.7)^{*}$ & $(1.68)$ & $(0.97)$ \\
Fin Depth & & & & & -0.11 & -0.19 \\
NFA & & & & & $(0.22)$ & $(0.37)$ \\
& & & & & & -0.0013 \\
R2 & & & & & & \\
F-stat & $44.1^{* * *}$ & $23.5^{* * *}$ & $17.05^{* * *}$ & $14.26^{* * *}$ & $11.14^{* * *}$ & $7.52^{* * *}$ \\
N & 46 & 46 & 46 & 46 & 46 & 43 \\
\hline
\end{tabular}

Estimation is OLS, with robust t-statistics in parentheses. All variables are measured as averages over 1975-2000. Output volatility is standard deviation of the growth rate of GDP; GDP-PC is average output per capita in log form; Size is log of population; Trade is log of (exports+imports)/output; $\operatorname{Vol}(\mathrm{TT})$ is standard deviation of the terms-of-trade, adjusted for variation in trade openness; Fin Depth is ratio of private credit to GDP; NFA is net foreign asset position. Data sources: Fin Depth is from Beck et al (2000) dataset; NFA is from Lane and Milesi-Ferretti (2001, updated); all other variables are from The World Bank's World Development Indicators online database. 
Table 3: Group Variation in Fundamental Characteristics

\begin{tabular}{llll}
\hline & IND & EASIA & LAC \\
\hline Vol(GDP) & 2.1 & 4.2 & 4.2 \\
Vol(TT) & 1.4 & 4.2 & 3.4 \\
GDP per capita & 22402 & 2789 & 2712 \\
Trade & 62.5 & 77.8 & 53.8 \\
Population & 35.8 & 68.1 & 20.5 \\
Financial Depth & 80.2 & 55.0 & 27.2 \\
Net Foreign Assets & -1.3 & -29.3 & -43.3 \\
\hline
\end{tabular}

See note to Table 2 .

Table 4: Cyclical Patterns

\begin{tabular}{lllll}
\hline & & IND & EASIA & LAC \\
\hline (1) & Savings Rate & 0.28 & 0.19 & 0.10 \\
& & $(4.19)^{* * *}$ & $(2.79)^{* * *}$ & $(3.25)^{* * *}$ \\
(2) & Current Account Surplus & -0.33 & -0.54 & -0.30 \\
& & $(4.19)^{* * *}$ & $(6.84)^{* * *}$ & $(7.94)^{* * *}$ \\
(3) & Fiscal Surplus & 0.26 & 0.15 & -0.04 \\
& & $(3.87)^{* * *}$ & $(2.02)^{* *}$ & $(1.15)$ \\
(4) & Tax Ratio & -0.07 & 0.049 & 0.002 \\
& & $(2.10)^{* *}$ & $(1.29)$ & $(0.11)$ \\
(5) & Real Exchange Rate & 0.08 & 1.05 & 0.54 \\
& & $(0.35)$ & $(5.01)^{* * *}$ & $(4.95)^{* * *}$ \\
\hline
\end{tabular}

Pooled estimation with country and time fixed effects. Data sources: Real exchange rate data are from Lane and Milesi-Ferretti (2000, updated); all other variables are from The World Bank's World Development Indicators online database. 